Publicação organizada pelo Programa de

Mestrado Profissional Stricto Sensu em

Engenharia Civil da Universidade São Judas

Volume 02 - Edição 01

Janeiro - Dezembro de 2019

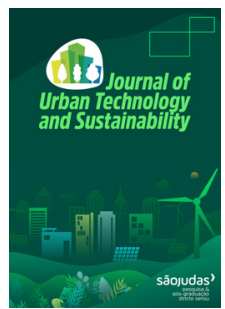

\title{
Application of surface modifiers in ceramic tile to improve adhesion strength with mortars
}

Bruna Bulzicoa, Maurício M. Resendea,", Carlos Herrera-Mesén ${ }^{b}$

a Department of Civil Engineering, São Judas Tadeu University, 546 Taquari St., São Paulo, 03166-000, Brazil.

${ }^{b}$ Department of Civil and Environmental Engineering, Barcelona Tech, Polytechnic University of Catalonia, UPC, Jordi Girona 1-3, 08034, Barcelona, Spain.

\section{Article info \\ Received 3 April 2019 \\ Received in revised form 14 \\ June 2019 \\ Accepted 20 June 2019 \\ Keywords \\ Adhesive mortar \\ Ceramic tiles \\ Adhesion tensile strength \\ Surface treatment}

\begin{abstract}
Nowadays, ceramic floor or wall tiles have been composed mainly of large ceramic tiles with low water absorption, which requires a greater need for bond strength between the tile and the adhesive mortar. Some researchers argue that adhesion is obtained mainly by mechanical interlocking, while others claim that adhesion is obtained mainly by increasing the contact surface. To provide this increase in the contact surface, some studies indicate the use of surface modifiers on the back of the ceramic plate. Thus, this research aimed to evaluate the influence of surface treatment on tensile strength. The research showed that factors such as the polymer content of the adhesive mortar, the absorption and the roughness of the ceramic back were more influential in the tensile strength than the use of the mentioned surface treatments.
\end{abstract}

\section{Aplicação de modificadores de superfície em placas cerâmicas para melhorar a resistência de aderência com argamassas}

\author{
Informações \\ Recebido 3 Abril 2019 \\ Manuscrito revisado recebido \\ 14 Junho 2019 \\ Aceito 20 Junho 2019 \\ Palavras-chave \\ Argamassas colantes \\ Revestimento cerâmico \\ Resistência de aderência à \\ tração \\ Tratamento superficial
}

\section{Resumo}

Hoje em dia, os ladrilhos cerâmicos de piso ou parede têm sido compostos principalmente por ladrilhos de cerâmica grandes dimensões e com baixa absorção de água, o que exige uma maior necessidade de resistência de união entre o ladrilho e a argamassa adesiva. Alguns pesquisadores argumentam que a adesão é obtida principalmente por intertravamento mecânico, enquanto outros afirmam que a adesão é obtida principalmente pelo aumento da superfície de contato. Para propiciar esse aumento da superfície de contato, algumas pesquisas indicam a utilização de modificadores de superfície no verso da placa cerâmica. Assim, esta pesquisa teve como objetivo avaliar a influência do tratamento superficial na resistência à tração. A pesquisa mostrou que fatores como o teor de polímeros da argamassa adesiva, a absorção e a rugosidade do verso da cerâmica foram mais influentes na resistência à tração do que o uso dos tratamentos de superfície mencionados.

\section{Aplicación de modificadores de superficie en baldosas para mejorar la resistencia de adherencia con morteros}

\section{Información}

Recibido 3 Abril 2019

Manuscrito revisado recibido

14 Junio 2019

Aceptado 20 Junio 2019

\section{Palabras clave}

Morteros adhesivos

Baldosas cerámicas

Resistencia de adherencia a

la tracción

Tratamiento superficial

\section{Resumen}

En la actualidad, los pavimentos o revestimientos cerámicos se han compuesto principalmente por grandes baldosas cerámicas de baja absorción de agua, lo que requiere una mayor necesidad de adherencia entre la baldosa y el mortero adhesivo. Algunos investigadores sostienen que la adhesión se obtiene principalmente mediante enclavamiento mecánico, mientras que otros afirman que la adhesión se obtiene principalmente aumentando la superficie de contacto. Para proporcionar este aumento en la superficie de contacto, algunos estudios indican el uso de modificadores de superficie en la parte posterior de la placa cerámica. Por lo tanto, esta investigación tuvo como objetivo evaluar la influencia del tratamiento superficial en la resistencia a la tracción. La investigación mostró que factores como el contenido de polímero del mortero adhesivo, la absorción y la rugosidad del dorso cerámico influyeron más en la resistencia a la tracción que el uso de los tratamientos superficiales mencionados.

\footnotetext{
* Corresponding author at: Department of Civil Engineering, São Judas Tadeu University, 546 Taquari St., 03166-000 São Paulo, Brazil. 


\section{Introduction}

Adherence is not an intrinsic property of mortar, as it also depends on the characteristics of the base. The mechanisms that promote this adhesion can be basically divided by thermodynamic mechanisms, chemical bonding and mechanical interlocking. Although there is a lot of research on the subject, there are differences of opinion between authors regarding the contribution of each of these adhesion mechanisms in the ceramic material / cementitious adhesion.

For Carasek et al. (1997) the adhesion of the hardened mortar to the base is essentially a mechanical phenomenon, which occurs due to the penetration of the binder paste or the mortar itself into the pores or between the roughness of the base. By contrast, for Costa (2014) the adhesion is predominantly chemical in nature, resulting from the molecular forces of attraction between the phases. These bonds can be of primary order: ionic, covalent, metallic and/or secondary, which are the intermolecular (van der Waals) forces. The author points out that the adhesion depends on complex parameters rather than on the simple absorption of the substrate, and consequently mechanical anchoring by the penetration of particles in the pores, relating the increased adherence to the increase of matrix-substrate contact. Mansur (2007) and Costa (2014) analyzed systems composed of ceramic substrates and substrate surface modifiers introduced by organosilanes. Authors found that this type of treatment promoted improved adherence at the interface by the possibility of hydrophobic and covalent interactions in addition to Van Der Waals existing interactions and hydrogen bonds. Mansur (2007) also evaluated that the introduction of polymers in the adhesive mortar altered the rheological properties of the mortar implying modification of the interfacial microstructure, when compared to the reference mortar.

In this context, this study aims to evaluate and compare the contribution of the surface treatment of silane and siliconate ceramic slabs to the use of polymer bonding mortars in the tensile bond strength of the ceramic tile/ bonding mortar interface.

\section{Materials and methods}

\subsection{Materials}

After a literature review on surface modifiers for surface treatment, it was defined to use as surface modifiers based on silane and siliconate. It was also decided to perform the treatment in ceramic tiles of two different classes of water absorption and of two types of adhesive mortars dosed in laboratory, with different contents of polymer (Figure 1).

For the characterization of the ceramic tiles used in the study, water absorption, apparent porosity, and tarnishing roughness factor (Table 1) were determined. The roughness factor, which is the ratio of the actual surface area (Ar) to the projected surface area in the plane, was obtained by laser interferometry using an optimal profilometer using a $5 \times$ zoom lens. and 2 micron resolution on the 3 axes in a region of $(4.5 \times 4.5) \mathrm{mm}$.

Regarding the characterization of the adhesive mortars, Table 2 presents the traces of the adhesive mortars and Table 3 presents the bond strength results of the adhesive mortars used in this phase of the study. To finalize the characterization of the materials, Table 4 presents the properties of the surface modifiers used in the study.

\subsection{Methods}

For interface analysis, the apparent contact angle, tensile strength and optical microscopy tests were

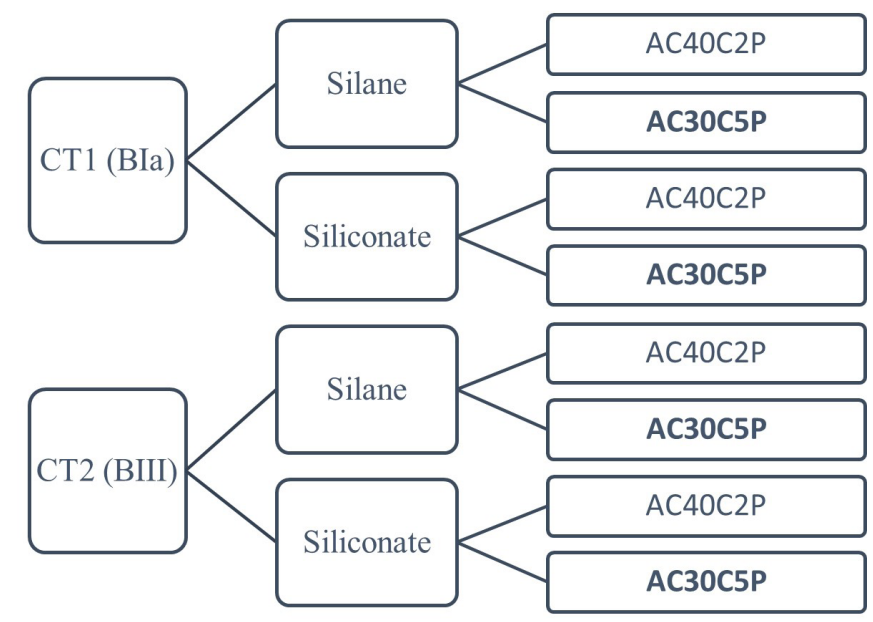

Fig. 1. Surface modifiers, ceramic tiles and mortars evaluated. 
Table 1. Water absorption and apparent porosity of ceramic tiles.

\begin{tabular}{cccc}
\hline $\begin{array}{c}\text { Ceramic } \\
\text { tile }\end{array}$ & $\begin{array}{c}\text { Water } \\
\text { absorption (\%) }\end{array}$ & $\begin{array}{c}\text { Apparent } \\
\text { porosity (\%) }\end{array}$ & $\begin{array}{c}\text { Factor of } \\
\text { roughness (r) }\end{array}$ \\
\hline CT 1 & 0.03 & 0.10 & 2.1 \\
CT 2 & 11.4 & 21.2 & 1.8 \\
\hline
\end{tabular}

Table 2. Composition of adhesive mortars (relative mass).

\begin{tabular}{ccc}
\hline Material & AC40C2P & AC30C5P \\
\hline Cement CP II F 40 & 1 & 1 \\
Quartz sand & 1.48 & 2.15 \\
Tylose & 0,005 & 0.005 \\
Calcium formiate & 0.01 & 0.01 \\
Vinnapas 5044N & 0.05 & 0.167 \\
Water/mortar ratio & 0.22 & 0.22 \\
Cement/mortar ratio & 0.40 & 0.30 \\
Polymer/mortar ratio & 0.02 & 0.05 \\
Polymer/cement ratio & 0.05 & 0.167 \\
\hline
\end{tabular}

Table 3. Characterization of adhesive mortars.

\begin{tabular}{ccc}
\hline Requirement & AC40C2P & AC30C5P \\
\hline $\begin{array}{c}\text { Tensile strength at 28 days, } \\
\text { normal curing }\end{array}$ & 2.0 & 0.9 \\
$\begin{array}{c}\text { Tensile strength at } 28 \text { days, } \\
\text { after immersion in water }\end{array}$ & 1.2 & 0.7 \\
$\begin{array}{c}\text { Tensile strength at 28 days, } \\
\text { after heat aging }\end{array}$ & 1.1 & 1.4 \\
$\quad$ Transverse deformation & 1.0 & 1.5 \\
\hline
\end{tabular}

Table 4. Properties of the surface modifier.

\begin{tabular}{ccc}
\hline Property & MS 1 & MS 2 \\
\hline Main compound & Silane & $\begin{array}{c}\text { Potassium } \\
\text { methyl-siliconate }\end{array}$ \\
Silane content (\%) & $99 \%$ & - \\
Solid content $(\%)$ & $99 \%$ & $55 \%$ \\
Density at $20{ }^{\circ} \mathrm{C}\left(\mathrm{g} / \mathrm{cm}^{3}\right)$ & 0.88 & 1.4 \\
\hline
\end{tabular}

proposed. Surface modifiers (silane and siliconate) were applied to the back of the two types of ceramic tiles (CT1, CT2). After the curing period of the surface modifiers, the contact angle of the back side of the treated and untreated ceramic tiles was determined by means of the goniometer. On the back of the two types of treated and untreated ceramic tiles, two types of laboratory-dosed adhesive mortars with different percentages of cement and polymers in their composition (AC4OC2P, AC30C5P) were applied. After 14 days of applying the adhesive mortars, the tensile bond strength and optical microscopy tests were performed.

\section{Results and discussion}

\subsection{Contact angle}

Table 5 presents the results of the contact angle of the ceramic tile latex with and without the presence of surface modifiers. Regarding the alteration of the surface wettability of the ceramic tiles by the surface treatment, the contact angle values obtained were statistically treated by analysis of variance (ANOVA). For this analysis we considered the null hypothesis $(\mathrm{HO})$ to be the one that considers that there is no difference between the surface tension of the tiles as a function of the surface treatment. As the P-value obtained from ANOVA was less than 0.05 and the $F$ value obtained was higher than the critical value, it can be concluded, as a 95\% confidence level, that the type of treatment, regardless of the type of ceramic tiles interferes with the contact angle value (Table $6)$.

The lowest contact angle was observed for the ceramic tiles with lower water absorption $(\mathrm{PCl})$, higher roughness factor and no surface treatment. This behavior can be explained by the fact that the water droplet tends to settle on the surface, filling the open spaces. Wenzel's model explains the wetting of rough surfaces by predicting that surface roughness enhances the wettability properties of solids, whether hydrophilic or hydrophobic. As expected, after silane application, their contact angle was increased, consequently their hydrophobicity.

For the ceramic tiles with the lowest roughness factor, high water absorption (CT2), there was the

Table 5. Average contact angle values for each type of ceramic tile with and without surface treatment.

\begin{tabular}{cccc}
\hline Ceramic tile & MS $\mathbf{1}\left(^{\mathbf{0}}\right)$ & MS $\mathbf{2}\left(^{\mathbf{0}}\right)$ & Untreated $\left(^{\mathbf{0}}\right)$ \\
\hline CT 1 & 105.9 & 88.7 & 86.3 \\
CT 2 & 115.3 & 119.5 & 127.3 \\
\hline
\end{tabular}

Table 6. Analysis of variance and F test to verify the influence of surface treatment on contact angle values for different types of ceramic tiles.

\begin{tabular}{cccc}
\hline Ceramic tile & $\mathbf{F}$ & F-critical & P-value \\
\hline CT 1 & 11.717 & 3.214 & $8.7 \mathrm{E}-05$ \\
CT 2 & 26.394 & 3.305 & $2.0 \mathrm{E}-07$ \\
\hline
\end{tabular}


opposite effect, the initial behavior showed a greater contact angle than after treatment with the water repellents. The behavior can be explained by Cassie and Baxter's model, in which the pores remain filled with air with the droplet on the surface, so that the droplet does not fill the pores of the substrate.

\subsection{Optical microscopy}

Figures 2 to 5 show some of the rupture interfaces obtained by optical microscopy for the highest cement content adhesive mortar (AC40C2P) and the lowest cement content (AC30C5P) and the type of surface treatment that presented the best and worst average bond strength for each type of ceramic tile.

From the optical microscopy images, it is noted that the rupture shape in the low water absorption ceramic tile (CT 1) did not change according to the type of treatment, but it is observed that, regardless of the type of adhesive mortar, the treatment with siliconate provides a void region at the interface, impairing adhesion to untreated and silane treated tiles. The silane-treated ceramic tile interface, on the other hand, is very similar to the untreated ceramic tile interface, providing in some situations a slightly better tensile adhesion strength.

The interface of the siliconate-treated ceramic tile a greater darkening of the adhesive mortar and the ceramic tile in this region than the untreated and silane-treated ceramic tile. This greater darkening should be due to the higher formation of hydrated mortar compounds, promoting greater adhesive mortar resistance and tensile adhesion strength.

Optical microscopy images of the higher water absorption ceramic tiles (CT 2) show a darkening of the adhesive mortar and the ceramic tile in the interface of the high water absorption ceramic tile (CT2) without treated and treated with silane.

\subsection{Tensile adhesion strength}

Table 7 and table 8 presents the results of tensile bond strength and the average results of tensile bond strength obtained for each of the situations. Overall, tests have shown that tensile adhesion strength does not only depend on ceramic tiles

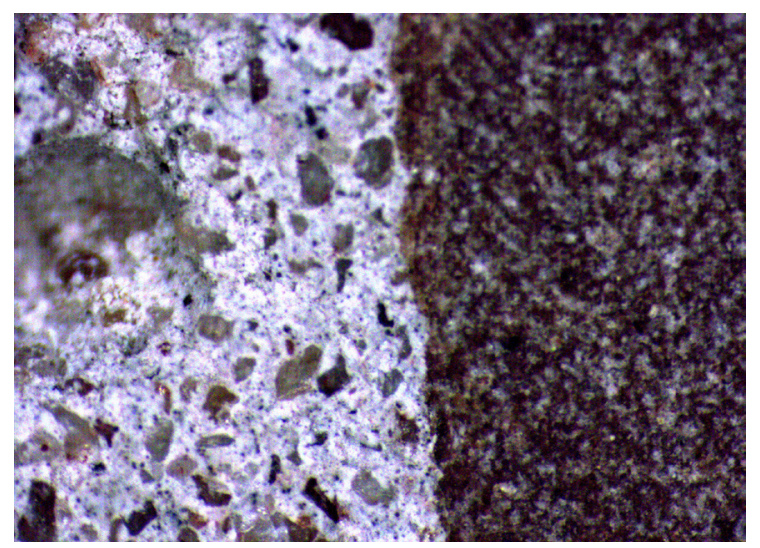

Fig. 2. Interface between silane surface-treated ceramic tile (CTI) and adhesive mortar AC30C5P.

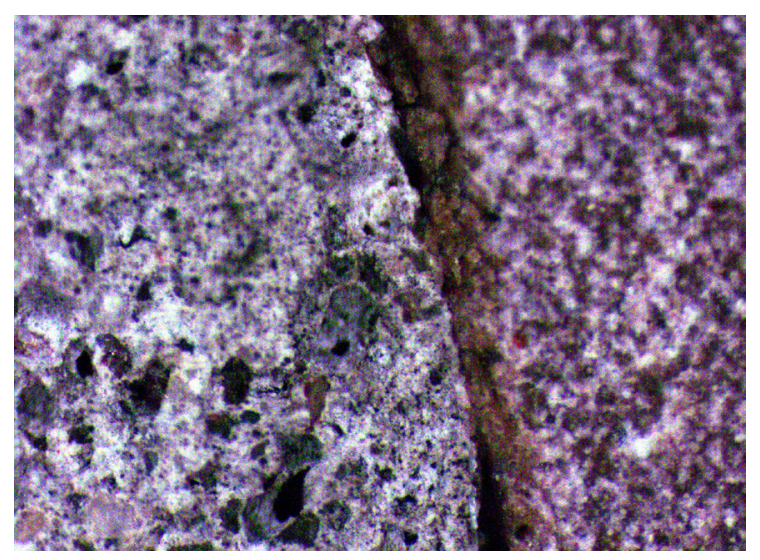

Fig. 3. Interface between siliconate surface-treated ceramic tile (CTI) and adhesive mortar AC40C2P.

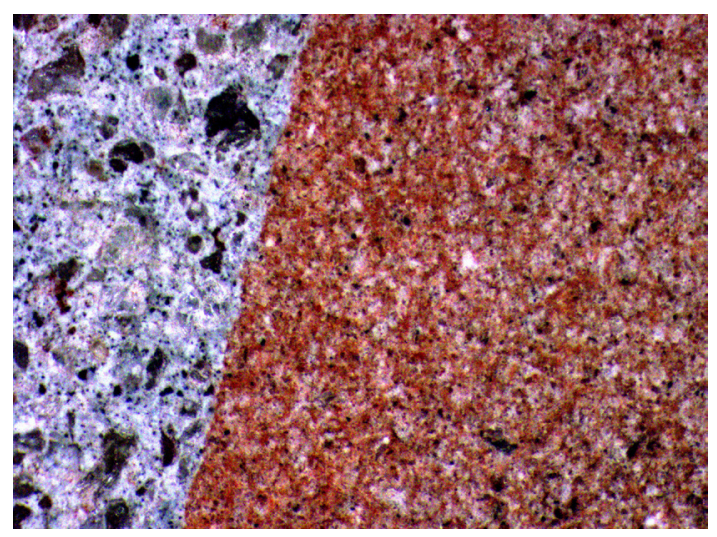

Fig. 4. Interface between silane surface-treated ceramic tile (CTI) and adhesive mortar AC30C5P.

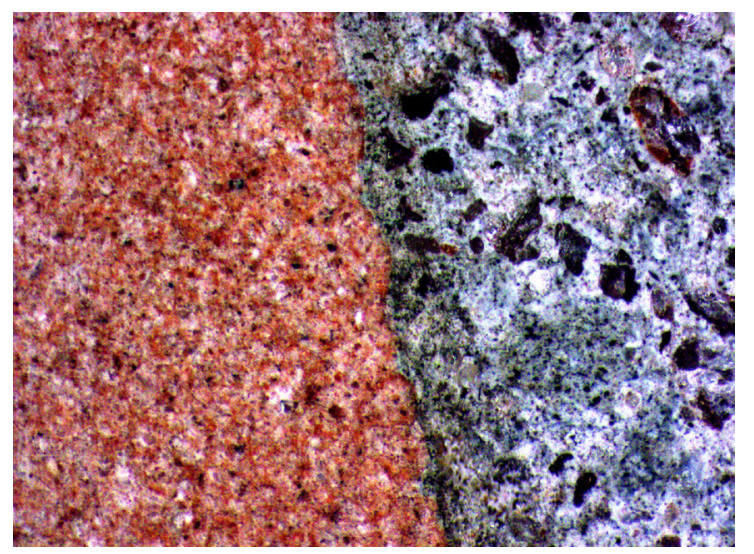

Fig. 5. Interface between silane surface treated ceramic tile (CTII) and adhesive mortar AC4OC2P 
Table 7. Average values of tensile strength for mortar AC4OC2P and with and without surface treatment

\begin{tabular}{cccc}
\hline Ceramic tile & MS 1 (MPa) & MS 2 (MPa) & $\begin{array}{c}\text { Untreated } \\
\text { (MPa) }\end{array}$ \\
\hline CT 1 & 0.48 & 0.07 & 0.60 \\
CT 2 & 0.29 & 0.66 & 0.55 \\
\hline \multicolumn{4}{c}{ Table 8. Average values of tensile strength for mortar } \\
AC30C5P and with and without surface treatment \\
\hline Ceramic tile & MS 1 (MPa) & MS 2 (MPa) & $\begin{array}{c}\text { Untreated } \\
\mathbf{( M P a )}\end{array}$ \\
\hline CT 1 & 1.19 & 0.33 & 1.08 \\
CT 2 & 0.67 & 1.08 & 1.31 \\
\hline
\end{tabular}

Table 9. Analysis of variance and F test to verify the influence of the type of surface treatment on the tensile adhesion strength for mortar AC4OC2P.

\begin{tabular}{cccc}
\hline Ceramic tile & $\mathbf{F}$ & F-critical & P-value \\
\hline CT 1 & 162.74 & 3.35 & $8.6 \mathrm{E}-16$ \\
CT 2 & 18.31 & 3.27 & $3.6 \mathrm{E}-6$ \\
\hline
\end{tabular}

Table 10. Analysis of variance and $F$ test to verify the influence of the type of surface treatment on the tensile adhesion strength for mortar AC30C5P.

\begin{tabular}{cccc}
\hline Ceramic tile & $\mathbf{F}$ & F-critical & P-value \\
\hline CT 1 & 73.73 & 3.28 & $6.7 \mathrm{E}-13$ \\
CT 2 & 34.11 & 3.28 & $9.3 \mathrm{E}-9$ \\
\hline
\end{tabular}

Table 11. Variation in tensile adhesion strength values as a function of surface treatment for mortar AC40C2P.

\begin{tabular}{cccc}
\hline Ceramic tile & $\begin{array}{c}\text { MS 1 vs } \\
\text { untreated }\end{array}$ & $\begin{array}{c}\text { MS 2 vs } \\
\text { untreated }\end{array}$ & MS 1 vs MS2 \\
\hline CT 1 & $-20 \%$ & $-88 \%$ & $85 \%$ \\
CT 2 & $-47 \%$ & $20 \%$ & $-128 \%$ \\
\hline
\end{tabular}

Table 12. Variation in tensile adhesion strength values as a function of surface treatment for mortar AC30C5P.

\begin{tabular}{cccc}
\hline Ceramic tile & $\begin{array}{c}\text { MS 1 vs } \\
\text { untreated }\end{array}$ & $\begin{array}{c}\text { MS 2 vs } \\
\text { untreated }\end{array}$ & MS 1 vs MS2 \\
\hline CT 1 & $10 \%$ & $-69 \%$ & $72 \%$ \\
CT 2 & $-49 \%$ & $-18 \%$ & $-61 \%$ \\
\hline
\end{tabular}

absorption to ensure satisfactory results for systems composed of cementitious matrices and ceramic tiles. The results show that the surface roughness of the tile can exert even greater importance than the water absorption of the ceramic tiles. Moreover, it can be observed that the type of treatment and the chemical composition of the adhesive mortar also significantly changed the tensile strength results.

Considering the null hypothesis $(\mathrm{HO})$ as the one that considers that there is no difference between the tensile adhesion strength as a function of mortar for the same type of surface treatment and ceramic tile, and by performing ANOVA statistical analysis, it can be concluded, with 95\% confidence (P-value less than 0.05 and $F>$ Critical), that the type of mortar interfered with the tensile adhesion strength value (Tables 9 and 10). Regarding the surface treatments of ceramic tiles, the ANOVA statistical variance analysis was performed, in which the null hypothesis $(\mathrm{HO})$ was considered to be the absence of difference between the tensile adhesion strength as a function of the surface treatment for the same mortar and ceramic tile. From the results obtained by this statistical analysis, it is considered that there was, with 95\% confidence (P-value less than 0.05 and $F>$ (ritical), the influence of surface treatment on the tensile adhesion strength, except for the medium water absorption ceramic tile (PCII) when using the adhesive mortar AC35C5P (Tables 9 and 10).

In general, as can be seen in Tables 11 and 12, it was found that the adhesive mortars dosed with higher polymer contents and lower cement concentrations presented more satisfactory results in tensile adhesion strength. This behavior was repeated for the two types of ceramic tiles and surface treatments. This result is in agreement with other researches that obtained similar results: Gonçalves (2004); Pereira et al. (2013); COSTA (2014). However, regarding the surface treatment of the surface, the results obtained contradict the results obtained by Costa (2014) which states that the silane hydrofuged bases have higher adhesion resistance than the untreated ones. According to Ohama (1998), modification of polymer mortars reduces shrinkage by drying, the modulus of elasticity and increases water retention, which leads to reduction of cracks and interface defects. For Almeida (2005), this type of addition reduces the amount of pores in the transition zone by densifying the paste at the interface, thereby increasing the mortar-ceramic tile contact surface and consequently the interactions that trigger the formation of intermolecular bonds from Van der Waals.

By analyzing the main characteristics of the 
ceramic tiles, the applied surface modifiers and the results obtained, each case can be explained separately. The ceramic tiles (low absorption) treated with silane and adhesive mortar AC30C5P, presented higher bond strength compared to reference substrates and treated with siliconate. This may be related primarily to the size of the silane particles, which, because they are very small, did not change the roughness of the ceramic tile, allowing the interlocking of the hardened mortar to the recesses of the ceramic tile.

Regarding the high water absorption ceramic tiles (CT2), the most satisfactory results were those related to the untreated ceramic tiles (reference) and the lower cemented and higher polymer content dosed adhesive mortar (AC30C5P), confirming the interlocking theory by the absorption and precipitation of cement hydration components as well as chemical adhesion. In contrast, surface treatments by reducing water absorption also reduced adherence.

\section{Conclusions}

This research showed the influence of polymer content on adhesive mortar on the performance of ceramic tile-adhesive mortar systems, showing that it is more effective in tensile bond strength than silane and siliconate surface modifier treatments.

Mortars dosed with higher polymer content presented higher tensile adhesion strengths, regardless of the surface conditions of the ceramic tiles. Analyzing the microscopy images, it was verified that the interfaces of the mortars with higher polymer contents presented less defects and denser aspect. Thus, the importance of chemical interactions and contact extension for adhesion is observed.

In relation to back of the ceramic tile, the application of surface modifiers did not generally increase the tensile bond strength, regardless of the ceramic tile water absorption class and the back roughness. The best tensile adhesion strength results were obtained on untreated ceramic tiles with surfaces with higher roughness factor.
In addition, this research has shown that the analysis of the surface roughness factor of the back of the ceramic tile is as or more important than the water absorption of ceramic tile to obtain a better tensile adhesion strength. In conclusion, the mechanical interlocking is directly linked to the adhesion extension, since the greater the surface roughness factor, the greater the contact area of the ceramic tile adhesion.

Finally, we note the importance of developing research on the roughness factor of the ceramic tile in order to contribute to the adhesion of the ceramic coating consisting of large tiles and low water absorption. Furthermore, it was shown that the tensile adhesion strength of the coating is more associated with the polymer content of the mortar than with the cement content.

\section{References}

ALMEIDA, A. E. F. S. Estudo da influência das adições de sílica ativa e copolímero estireno acrílico nas propriedades de argamassas para assentamento de porcelanato. 2005. Tese (Doutorado em Ciência e Engenharia de Materiais) - Ciência e Engenharia de Materiais, Universidade de São Paulo, São Carlos, 2005.

CARASEK, H.; CASCUDO, O.; CINCOTTO, M. A.; DJANIKIAN, J.G.. Microestrutura da interface argamassa / tijolo cerâmico. Anais.. Salvador: Ceta/ Antac, 1997.

\section{COSTA, E. B. C. Análise de parâmetros influentes} na aderência de matrizes cimentícias. 2013. Tese (Doutorado em Engenharia de Construção Civil e Urbana) - Escola Politécnica, Universidade de São Paulo, São Paulo, 2013.

GONÇALVES, S. R. C. Variabilidade e fatores de dispersão da resistência de aderência nos revestimentos em argamassa: estudo de caso. 2004. Dissertação (Mestrado em Estruturas e Construção Civil) - Universidade de Brasília, Brasília, 2004.

MANSUR, A. A. P. Mecanismos físico-químicos de 
aderência na interface argamassa modificada com polímeros/cerâmica de revestimento. 2007. Tese (Doutorado em Engenharia Metalúrgica) Escola de Engenharia - Universidade Federal de Minas Gerais, Belo Horizonte, 2007.

OHAMA, Y. Polymer-based Admixtures. Cement and Concrete Composites, v. 20, p. 189-212, 1998.

PEREIRA, E.; SILVA, I. J.; COSTA, M. R. M. M. Avaliação dos mecanismos de aderência entre argamassa colante e substrato não poroso. Ambiente Construído, v. 13, n. 2, p. 139-149, 2013. 